\title{
Efficient gene delivery into mammalian cells by baculovirus vector in vitro
}

\author{
I. N. Vagyna, O. V. Anopriyenko, O. A. Zaharuk, V. F. Gorchev', \\ L. I. Strokovska, A. P. Solomko
}

Institute of molecular biology and genetics NAS of Ukraine 150, Zabolotnogo Str, Kyiv Ukraine, 03680

${ }^{1}$ Palladin Institute of Biochemistry of the NAS of Ukraine

9 Leontovicha Str., Kyiv, Ukraine, 01601

solomko@imbg.org.ua

\begin{abstract}
The recombinant baculovirus vector with EGFP reporter gene under the control of strong CAG promoter cassette was used for transduction of normal (HEK293) and tumor (HeLa) human cell lines. Dependence of transduction efficiency on the virus dose, time of virus incubation, temperature and cell type is shown. Transient reporter gene expression gradually diminished and was detected in single cells on the $15^{\text {th }}$ day after transduction.
\end{abstract}

Keywords: recombinant baculovirus, AcMNPV, transduction, transient expression, gene therapy.

Introduction. The ability of baculoviruses to transduce efficiently various mammalian cells and tissues in vivo and in vitro has been discovered lately [1-3] and became a reason to study their potential as a vector for cell engineering and gene therapy $[4,5]$. Comparing to other viral vector systems baculoviruses possess a number of advantages, including virus inability to replicate in mammalian cells [6], a wide spectrum of transducible cell and tissue types with apparent lack of cytotoxicity [4], the capacity to sustain large (up to $30 \mathrm{~kb}$ ) heterologous DNA fragments due to the genome and viral particles structure, etc. [7]. AcMNPV and BmNPV nuclear polyhedrosis viruses-based vectors have been used to

(C) I. N. VAGYNA, O. V. ANOPRIYENKO, O. A. ZAHARUK, V. F. GORCHEV, L. I. STROKOVSKA, A. P. SOLOMKO, 2008 deliver genes into mammalian cells [4, 7]. Baculovirus-integrated genes have been expressed in mammalian cells under the control of CMV IE and the Rous sarcoma virus (RSV) promoters [1,8].

The aim of the work was to specify the optimal conditions for transduction of normal and tumorous mammalian cell lines by baculoviruses to provide a high level of exogenous gene expression in recombinant baculovirus vectors. The expression of EGFP reporter gene in mammalian cells was regulated by the CAG promoter cassette which appeared to be a stronger regulator than the CMV and RSV promoters in certain cell types [2].

Materials and methods. Cell cultures and viruses. Sf21 adherent insect cells were grown in TC-100 medium ("Sigma", USA) supplemented with $10 \%$ fetal 
bovine serum (FBS, "Sigma") at $28^{\circ} \mathrm{C}$. The cells were infected with baculoviruses according to standard procedures [9].

HEK293 (human embryonic kidney) and HeLa (human epithelial cervix carcinoma) cell lines used in (the) work have been received from the Russian Cell Cultures Collection (St. Petersburg). The cells were maintained in DMEM medium ("Sigma") supplemented with $10 \%$ FBS at $37^{\circ} \mathrm{C}$ in the $\mathrm{CO}_{2}$-incubator.

Construction of recombinant baculoviruses. Recombinant baculoviruses were obtained on the basis of Autographa californica multiple nuclear polyhedrosis virus (AcMNPV) in Bac-to-Bac expression system ("Invitrogen", USA). The recombinant baculovirus vector with $\mathrm{CAG}$ expression cassette was constructed on the basis of pFastBac1 shuttle vector. CAG cassette has been excised with SpeI and HindIII ("Fermentas", Lithuania) from the baculovirus transfer vector pBacMam-1 ("Invitrogen"). EGFP gene was obtained from the pEGFP-C1 vector plasmid ("Clontech", USA) as Eco47III-KpnI fragment and cloned into the polyclonal site between the promoter and the sequence of polyadenylation signal on the SmaI and KpnI restriction sites.

Transfection was carried out using the CellFECTIN reagent ("Invitrogen"). The virus was concentrated by centrifugation at $100000 \mathrm{~g}$. The virus titer after amplification and concentration comprised $(2-4) * 10^{8} \mathrm{pfu} / \mathrm{ml}$.

Transduction of mammalian cells by recombinant baculoviruses. The cells were seeded into 6-well plates at the concentration $2 * 10^{5}$ cells per well in DMEM cultural medium with $10 \%$ FBS and antibiotics, and incubated at $37^{\circ} \mathrm{C}$ in $\mathrm{CO}_{2}$-incubator for 12 hours. The cultural medium was removed, cells were washed with D-PBS phosphate buffer (Dulbecco PBS, without $\mathrm{Ca} 2+$ and $\mathrm{Mg} 2+$ ions), and the recombinant baculovirus was added at concentration of 20, 200 and 500 moi (multiplicity of infection $=$ pfu quantity per cell). The final volume of PBS per well was set up to 500 microliters. Then the optimized transduction method was applied [4]. In all variants the cells were incubated for 4 hours at $28^{\circ} \mathrm{C}$, then $1.5 \mathrm{ml}$ of DMEM were added and cells were cultivated for 16 hours at

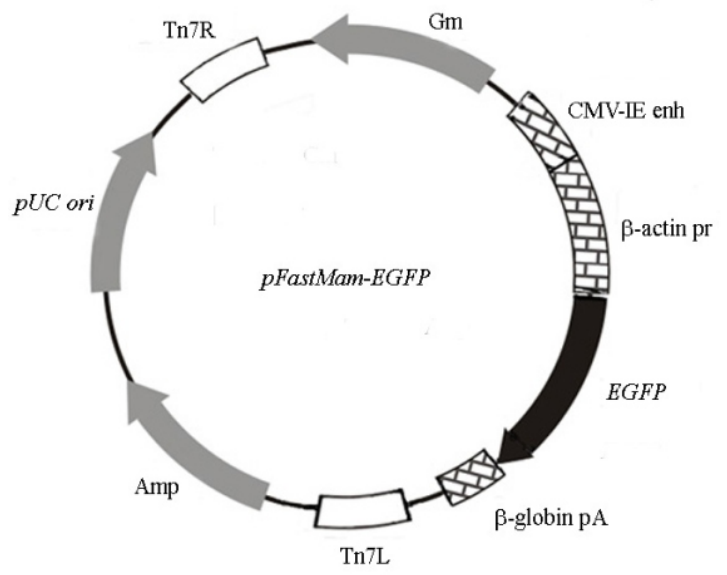

Fig. 1. Construction of the pFastMam-EGFP vector used for generation of the recombinant baculovirus vector AcMNPV-EGFP. The polyhedrin gene promoter was changed into combined element, comprising IE-enhancer of the cytomegalovirus (CMV IE enh) and the promoter of chicken $\beta$-actin gene ( $\beta$-actin pr).

$37^{\circ} \mathrm{C}$. At the end of the incubation period the solution with virus was removed, the cells were washed with PBS, $2 \mathrm{ml}$ of MDEM with $10 \%$ FBS were added, and the cells were cultivated for 24 hours at $37^{\circ} \mathrm{C}$. After the procedure cells were harvested and analyzed with flow cytometer.

Fluorescent microscopy and flow cytometry. The transduction efficiency was assessed as a percentage of cells, expressing fluorescent protein, using Coulter Epics XL flow cytometer after the preliminary examination of cells on the fluorescent microscope (Micmed-2EC). The cells for cytometry were harvested by trypsinization $(0.25 \%$ tripsin and $0.02 \%$ EDTA at 1:1 ratio) and resuspended in D-PBS (without $\mathrm{Ca}^{2+}$ and $\mathrm{Mg}^{2+}$ ) supplemented with FBS (5\%) up to the density of $(1-5)^{*} 10^{5}$ cells $/ \mathrm{ml} .10000$ signals were analyzed for each sample. The cells transduced by the AcMNPV virus without EGFP were used as a negative control. (The) Statistical analysis of transduction results was carried out according to standard methods [10] with Microsoft Excel presentation.

Results and discussion. The recombinant baculovirus vector AcMNPV-EGFP, containing the EGFP reporter gene under the control of strong CAG promoter cassette, was constructed in order to optimize the transduction of mammalian cells of different origin by the recombinant baculoviruses (Fig. 1). The CAG cassette with cytomegalovirus IE-enhancer, chicken 


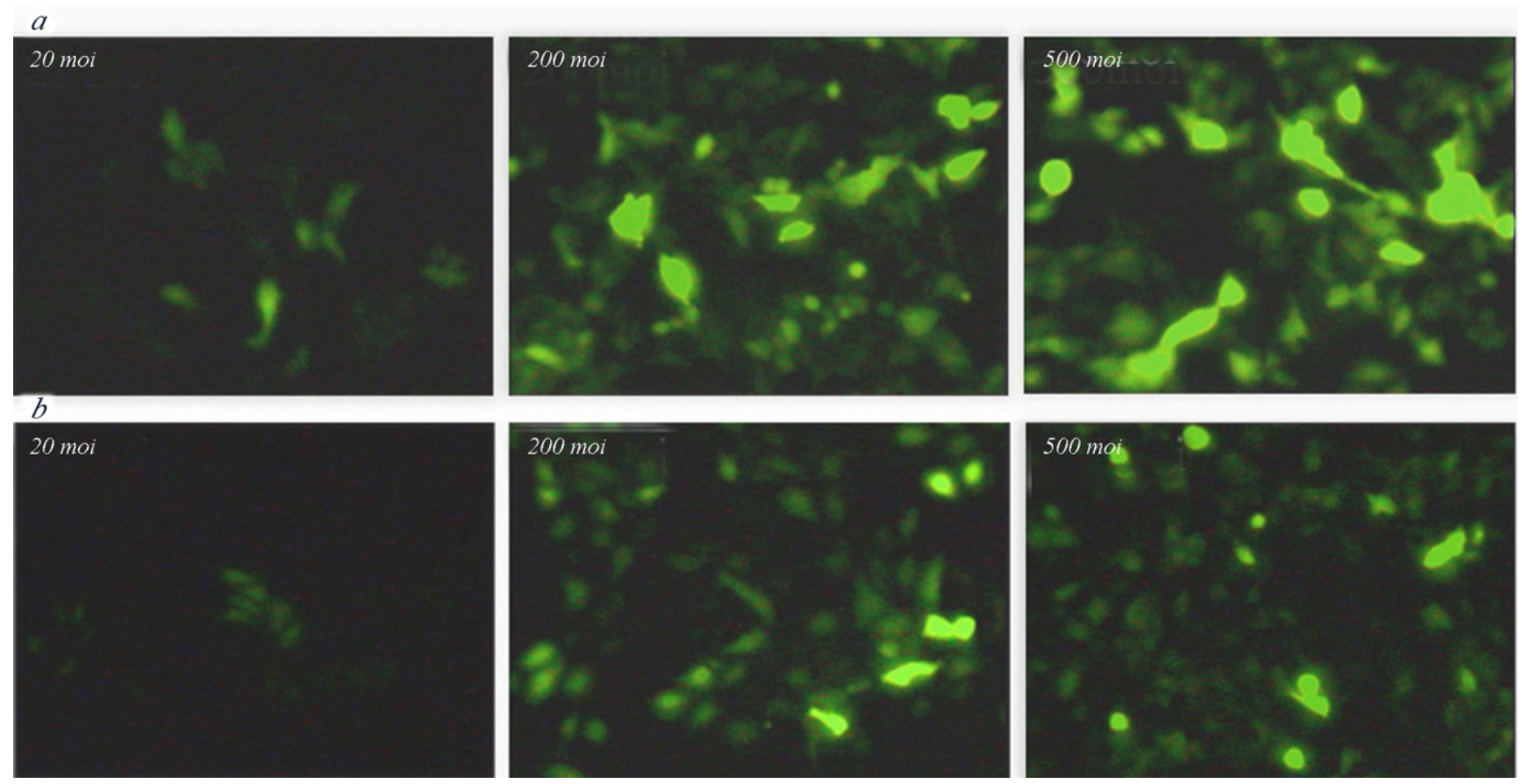

Fig. 2. Fluorescent microscopy of the cells transduced by different dose of AcMNPV-EGFP recombinant baculovirus (x100 magnitude). A Transduction of HEK293 cell line. B Transduction of HeLa cells. Virus dose in moi (multiplicity of infection = pfu quantity per cell) is shown in the upper left corner of the photos

$\beta$-actin gene promoter and rabbit $\beta$-globin gene polyadenylation signal efficiently drives expression in many cell types and appears to be more powerful regulator than the CMV and RSV promoters [2].

The efficiency of mammalian cell transduction by the baculoviruses varies widely and depends on a cell type. HEK293 and HeLa cell lines have been chosen to optimize the method since they demonstrated sufficiently high transduction level $[4,11]$.

HEK293 and HeLa cells were transduced by recombinant AcMNPV-EGFP baculovirus with varying multiplicity of infection per cell (20,200 and $500 \mathrm{moi}$ ) at $28^{\circ} \mathrm{C}$ for 4 hours in PBS solution. The transduction efficiency raised with increasing virus dose for both HEK293 cell line (comprising 38, 86 and $96 \%$ respectively) and HeLa cell line (35, 73 and $80 \%$ ) (Fig. 2). The obtained results demonstrate proportional dependency of the transduction efficiency on the baculovirus dose that coincides with the information from literature $[4,12]$. However, high concentrations of the recombinant virus ( 800 moi and above) can result in overload of a mammalian cell with viral genome and cause the cell metabolism disruption, provoking mitosis slowdown and viability decrement
[5]. The optimal virus dose, selected in our experiments, was 500 moi ( $96 \%$ of flourescen cells for HEK 293 line and $80 \%$ for the cells of HeLa line). The virus dose of 200 moi was also sufficiently effective ( 86 and $73 \%$ respectively).

Besides the virus concentration, the incubation period is a factor influencing transduction efficiency $[4,11,12]$. In different studies the incubation period with the recombinant baculoviruses varied from 1 [6] to 24 [11] hours. There was observed a positive correlation between fluorescent intensity and incubation period, especially at high virus concentrations. It was shown that the probability of baculovirus entry into mammalian cells rises with the enlargement of incubation period and virus dose [12]. However, there is information [11] indicating that the prolongation of incubation period can have a negative influence on the mammalian cell proliferation, especially when the cells are under nonpermissive conditions (cultural medium and temperature).

The temperature is a significant factor influencing the degree of baculovirus transduction of the cells. The incubation temperature for recombinant baculoviruses and mammalian cells in different studies varies from 4 


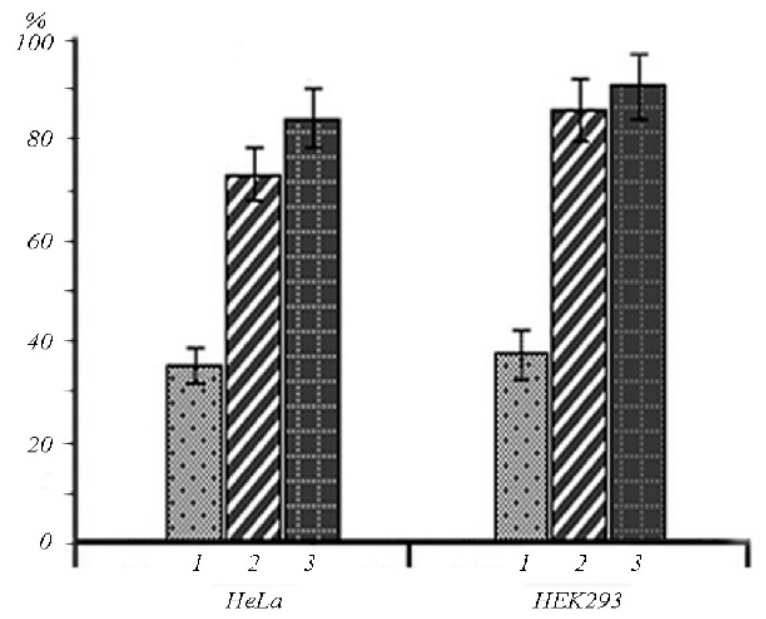

Fig. 3. Dose-dependent efficiency of mammalian cells transduction by the recombinant baculovirus AcMNPV-EGFP under the optimized transduction conditions.

to $37^{\circ} \mathrm{C}[11,12]$. The most effective mammalian cell transduction by the baculoviruses has been observed at $25-28{ }^{\circ} \mathrm{C}$. It was found out that baculovirus titer diminished significantly at $37{ }^{\circ} \mathrm{C}$ and after 12 hours comprised $30 \%$ of the initial virus quantity. The comparison of transduction efficiency of the AcMNPV-EGFP recombinant baculovirus in our trial experiments showed that at the virus dose of 200 moi this character is essentially higher for HEK293 cell line at $28{ }^{\circ} \mathrm{C}(86 \%$ as compared to $51 \%)$. For HeLa cells the character remained practically on the same level $(72-73 \%)$.

For different cell lines the preferable transduction medium in some cases was DMEM, in others - D-PBS solution. As it was demonstrated previously $[4,12]$, the maximum transduction efficiency had been achieved using D-PBS. In the work [11] the transduction was carried out directly in cultural medium for insect cells without centrifugation for virus concentration that simplified and accelerated the procedure significantly. However, with this approach the optimal virus-to-cell ratio is achieved due to significant increase of incubation medium volume which leads to transduction efficiency decrement (according to our preliminary data). Moreover, the application of viral supernatant for transduction in some cases results in the inhibition of mammalian cells growth [11]. The viral inoculum dilution with D-PBS solution leads to higher transduction efficiency [13]. The application of
DMEM cultural medium in this variant did not result in a good transfection. Thus, after the trial experiments D-PBS solution was used in our study.

Considering the above mentioned data and results of the trial experiments we determined the optimal conditions of two-stage transduction. On the first stage the cells were incubated with recombinant baculovirus for 4 hours at $28{ }^{\circ} \mathrm{C}$ in D-PBS solution. On the second stage the solution concentration was three-fold diminished by adding $1.5 \mathrm{ml}$ of DMEM medium with $10 \%$ FBS and the cells continued to be incubated with the recombinant baculovirus for 16 hours at $37^{\circ} \mathrm{C}$. This combined approach made it possible to maintain permissive conditions for both virus and mammalian cells that promotes effective virus transfer into cells. Under these conditions the transduction level of normal (HEK293) and tumor (HeLa) cells was rather similar in value in accordance with the virus dose.

The maximum quantity of cells expressing the fluorescent protein was observed at 24 and 48 hours posttransduction. The significant amount of fluorescent cells persisted on the 9th day, but the reporter gene expression decreased gradually, persisting in single transduced cells for 15 days.

The growing interest toward baculoviruses stimulated endeavor to characterize in details the processes attending the recombinant baculovirus entry into mammalian cells in vivo and in vitro $[4,7]$. Although the apparent lack of cytotoxicity even at high virus dose (500 moi) is an evidence of safety and advantage of the baculoviruses, the key objective of the insect viruses' application as vectors for gene therapy requires further investigation. The studies on the potential of recombinant baculoviruses for genetic engineering, including stem cells transduction, small interfering RNA delivery, study of gene functions, etc. $[5,13]$ demonstrate the prospects in these fields. A possible application of the baculoviruses in the antitumor therapy assumes several approaches, for example, different variants of vaccination strategy or anticancer agent expression in the baculovirus vectors. The deeper comprehension of the baculovirus biology and the virus interaction with mammalian cells will promote more effective and purposeful application of the insect viruses. 
И. Н. Вагина, О. В. Аноприенко, Е. А. Захарук, В. Ф. Горчев,

Л. И. Строковская, А. П. Соломко

Эффективность доставки генов бакуловирусами в клетки млекопитающих in vitro

Резюме

Рекомбинантный бакуловирусный вектор, содержащий репортерный ген ЕGFP под регуляцией сильной промоторной кассеты CAG, использовали для трансдукиии нормальной (НЕК293) и опухолевой (HeLa) клеточных линий человека. Показана зависимость эффективности трансдукиии от дозы вируса, времени инкубации с вирусом, температуры и типа клеток. Экспрессия репортерного гена носила временный характер и, постепенно уменьшаясь, детектировалась в единичных клетках на 15-е сут после трансдукиии.

Ключевые слова: рекомбинантный бакуловирус, AcMNPV, трансдукиия, временная экспрессия, генная терапия.

I. М. Вагіна, О. В. Анопрієнко, О. А. Захарук, В. Ф. Горчев, Л. І. Строковська, О. П. Соломко

Ефективність транспортування генів бакуловірусами в клітини ссавців in vitro

Резюме

Рекомбінантний бакуловірусний вектор, який містить репортерний ген EGFP під регуляцією сильної промоторної касети $C A G$, використано для трансдукиії нормальної (HEK293) і пухлинної (HeLa) клітинних ліній людини. Показано залежність ефективності трансдукиї від дози вірусу, часу інкубації з вірусом, температури і типу клітин. Експресія репортерного гена мала тимчасовий характер, поступово зменшувалась і детектувалась у поодиноких клітинах на 15-ту добу після трансдукиії.

Ключові слова: рекомбінантний бакуловірус, AcMNPV, трансдукція, тимчасова експресія, генна терапія.

\section{REFERENCES}

1. Hofmann C., Sandig V., Jennings G., Rudolph M., Schlag P., Strauss $M$. Efficient gene transfer into human hepatocytes by baculovirus vectors // Proc. Nat. Acad. Sci. USA.-1995. -92, N 22.-P. 10099-10103.

2. Shoji I., Aizaki H., Tani H., Ishii K., Chiba T., Saito I., Miyamura T., Matsuura $Y$. Efficient gene transfer into various mammalian cells, including non-hepatic cells, by baculovirus vectors // J. Gen. Virol.-1997.-78, N 10.-P. 2657-2664.

3. Tani H., Limn C. K., Yap C. C., Onishi M., Nozaki M., Nishimune Y., Okahashi N., Kitagawa Y., Watanabe R., Mochizuki R., Moriishi K., Matsuura Y. In vitro and in vivo gene delivery by recombinant baculoviruses // J. Virol.2003.-77, N 18.-P. 9799-9808.

4. Kenoutis C., Efrose R. C., Swevers L., Lavdas A. A., Gaitanou M., Matsas R., Iatrou K. Baculovirus-mediated gene delivery into mammalian cells does not alter their transcriptional and differentiating potential but is accompanied by early viral gene expression // J. Virol. -2006.-80, N 8.-P. 4135-4146.

5. $Н$ и Y.-C. Baculovirus vectors for gene therapy // Insect viruses: biotechnological applications / Ed. D. C. Bonning.- New York: Elsevier, 2006.-Vol. 68.-P. 287-320.

6. Condreay J. P., Witherspoon S. M., Clay W. C., Kost T. A. Transient and stable gene expression in mammalian cells transduced with a recombinant baculovirus vector // Proc. Nat. Acad. Sci. USA.-1999.-96, N 1.-P. 127-132.

7. Fujita R., Matsuyama T., Yamagishi J., Sahara K., Asano S., Bando $H$. Expression of Autographa californica multiple nucleopolyhedrovirus genes in mammalian cells and upregulation of the host beta-actin gene // J. Virol.-2006.-80, N 5.-P. 2390-2395.

8. Boyce F. M., Bucher N. L. Baculovirus-mediated gene transfer into mammalian cells // Proc. Nat. Acad. Sci. USA.1996.- 93, N 6.-P. 2348-2352.

9. King L. A., Possee R. D. The baculovirus expression system. A laboratory guide.-London: Chapmann and Hall, 1992.$220 \mathrm{p}$.

10. Лакин Г. Ф. Биометрия.-М.: Высш. шк., 1990.-352 с.

11. Cheng T., Xu C. Y., Wang Y. B., Chen M., Wu. T., Zhang J., Xia N.S. A rapid and efficient method to express target genes in mammalian cells by baculovirus // World J. Gastroenterol.-2004.-10, N 11.-P. 1612-1618.

12. Hsu C. S., Ho Y. C., Wang K. C., Hu Y. C. Investigation of optimal transduction conditions for baculovirus-mediated gene delivery into mammalian cells // Biotechnol. Bioeng.2004.-88, N 1.-P. 42-51.

13. Kost T. A., Condreay J. P., Jarvis D. L. Baculovirus as versatile vectors for protein expression in insect and mammalian cells // Nat. Biotechnol.-2005.-23, N 5.-P. 567-575.

UDC 578.841:578.23

Received 18.07.08 